\title{
Theoretical Explanations of Jyoshi Kousei Business ("JK Business") in Japan
}

Mutsumi Ogaki

California State University, Fresno, mutsumiogaki@gmail.com

Follow this and additional works at: https://digitalcommons.uri.edu/dignity

Part of the Criminology Commons, Gender and Sexuality Commons, Inequality and Stratification Commons, Regional Sociology Commons, Social Control, Law, Crime, and Deviance Commons, and the Sociology of Culture Commons

\section{Recommended Citation}

Ogaki, Mutsumi (2018) "Theoretical Explanations of Jyoshi Kousei Business ("JK Business") in Japan," Dignity: A Journal of Analysis of Exploitation and Violence: Vol. 3: Iss. 1, Article 11. https://doi.org/ 10.23860/dignity.2018.03.01.11

This Research and Scholarly Article is brought to you for free and open access by DigitalCommons@URI. It has been accepted for inclusion in Dignity: A Journal of Analysis of Exploitation and Violence by an authorized editor of DigitalCommons@URI. For more information, please contact digitalcommons-group@uri.edu. 


\title{
Theoretical Explanations of Jyoshi Kousei Business ("JK Business") in Japan
}

\begin{abstract}
Jyoshi kousei (JK) means high school girls in Japanese and "JK business" is an umbrella term for commercial activities done by high school girls to provide male customers with sexual arousal. The "JK business" is considered to promote sexual exploitation or sexual assault of minors. Currently, only two prefectures out of 47 in Japan enforce ordinances that specifically regulate the "JK business." This paper intends to explore possible theoretical explanations of the "JK business" to raise awareness on the issue. Gendered pathways theory and sexual script theory are selected as the primary source of the discussions. Policy implications and future research recommendations derived from the discussion are provided.
\end{abstract}

\section{Keywords}

Japan, jyoshi kousei business, sexual exploitation, minors, sexual assault, "JK business, " gendered pathways theory, sexual script theory

\section{Creative Commons License}

\section{(c) (i) (9)}

This work is licensed under a Creative Commons Attribution-Noncommercial-No Derivative Works 4.0 License.

\section{Acknowledgements}

The author would like to express her sincere appreciation to Dr. Keith E. Clement, professor, Department of Criminology, California State University, Fresno, USA, for his continuous guidance, advice, and encouragement. The author also wishes to thank the editor-in-chief of Dignity, Donna Hughes, and the reviewers for their insightful comments and comprehensive advice on earlier versions of this paper. Dignity thanks the following people for their time and expertise in reviewing this paper: Cassini Sai Kwan Chu, honorary lecturer, Department of Sociology, The University of Hong Kong; Erin C. Heil, associate professor, Department of Criminal Justice Studies, Southern Illinois University, Edwardsville, USA; and Christine Zozula, assistant professor, Sociology and Anthropology Department, University of Rhode Island, USA. 


\section{DIGNITY}

Volume 3, Issue 1, Article 11, 2018
A JOURNAL ON

SEXUAL EXPLOITATION

AND VIOLENCE

https://doi.org/10.23860/dignity.2018.03.01.11

\title{
THEORETICAL EXPLANATIONS OF JYOSHI KOUSEI ("JK BUSINESS") IN JAPAN
}

\author{
Mutsumi Ogaki \\ California State University, Fresno
}

\begin{abstract}
Jyoshi kousei (JK) means high school girls in Japanese and "JK business" is an umbrella term for commercial activities done by high school girls to provide male customers with sexual arousal. The "JK business" is considered to promote sexual exploitation or sexual assault of minors. Currently, only two prefectures out of 47 in Japan enforce ordinances that specifically regulate the "JK business." This paper intends to explore possible theoretical explanations of the "JK business" to raise awareness on the issue. Gendered pathways theory and sexual script theory are selected as the primary source of the discussions. Policy implications and future research recommendations derived from the discussion are provided.
\end{abstract}

\section{KEYWORDS}

Japan, jyoshi kousei, sexual exploitation, minors, sexual assault, “JK business,” gendered pathways theory, sexual script theory

I was desperate. And if sex was all it took to make me stop feeling so worthless, I thought I was game for anything (Osaki, 2014).

$O$ exual exploitation of minors has a long history all over the world, and Japanese society is not an exception. Statistically, prostitution of minors has decreased while the forms of sexual exploitation of minors continue to grow due to the development of the internet and technology (Human Rights Council, 2016). Out of trends and phenomena that exploit minors, the "JK business" deserves particular attention. JK stands for jyoshi kousei or high school girls in Japanese, and the "JK business" can take on a variety of forms of commercial activities done by high school girls (Human Rights Council, 2016; Adelstein \& Kubo, 2015). Such a business does not necessarily result in sexual contacts between the two parties. However, the Metropolitan Police Department in Tokyo, Japan warns that based on their reports the female minors' involvement in sex businesses can increase the possibility of physical consequences such as sexual assault or stalking, or psychological impacts including depression and anxiety (The Metropolitan Police Department, 2017; Mason \& Lodrick, 2013). In spite of these potential risks associated with the "JK businesses," not enough actions have been taken by the Japanese 
government. One of the reasons is because the "JK businesses" are still a rising issue. Therefore, there is a significant need for theoretical explanations of the "JK businesses" to raise awareness to better regulate the businesses and protect minors from being exploited. To explain why "JK businesses" started and are flourishing in Japan, the author explores the roles of gender and culture in the development of the sexual exploitation of female minors. This paper aims to assess a possible theoretical explanation of the "JK business" utilizing gendered pathways theory and sexual script theory. The cultural background and current legal framework are discussed.

\section{Cultural Background}

According to Okunuki (2015), the etymology of the "JK businesses" can date back to the 1990s with a trend of buru sera, teenage girls selling their worn and unwashed school uniforms and swimwear to male fetishists (Okunuki, 2015). The trend of buru sera was a product of social phenomena of the 1980s through the 1990s based on O-nyanko Cluba, popular female idol group in Japan (Richardson, 2016). Their most well-known song's title can be translated into "Please don't take off my school uniform," which was released in 1985. The song contained sexually provocative lyrics and was performed by the members of the band who dressed in school uniforms. Male fans of this group who were adolescents when the song was popular grew up to have more money to spare by the 1990s. Meanwhile, Japan was experiencing the so-called bubble economy as a result of the rapid growth of its financial market. Some researchers claim that financial overconfidence contributed to the liberalization of society in the form of being more open to sex as a whole society (Colombo, 2012). This change was the result of Japanese people trying to mimic the western lifestyle. Moreover, after the bubble economy "popped" and the economy went down, there were enough number of companies that were desperate enough to be the medium between high school girls and male customers (Richardson, 2016). All of these factors supported the birth of the buru sera business.

When the trend of buru sera business declined, a more obvious form of sales of the girls became popular in urban cities in Japan. It is called enjo kosai, which is often translated as "compensated dating." Ueno (2003) introduced a literal translation of enjo kosai, which is "a relationship with support" and this translation can give readers an insight into enjo kosai. Affluent middle-aged men offered the young women financial support in exchange for sexual relationships. From the term enjo kosai, several meanings can be inferred. First, enjo (support or assistance) implies an excuse for the sexual contract and the payment pardons men from feeling guilty and almost turns the relationship into a volunteer activity. Ueno (2003) also pointed out that social cognition that enjo kosai is a cynical euphemism for teenage prostitution was established by 1990s. Therefore, one of the reasons the society continued using the term enjo kosai could have been their effort to differentiate enjo kosai from the traditional form of prostitution. In this context, the term kosai (relationship or dating) can imply a degree of intensity in the relationship between the girls and the clients, which romanticizes the relationship leading to the distinction of two types of sex businesses. Also, the term kosai implies pseudo-romance and might have attracted young girls who lacked the experience of dating or longed for emotional attachment. Another implication is the value placed on the young girls. If the men just wanted to have sexual intercourse, they could have purchased professional prostitutes because they were wealthy enough 
to financially support the girls. However, they intentionally chose those non-professional women, and in the 1990s even younger girls were targeted.

The most recent form of sexual exploitation of minors in Japan is the "JK business". There are various types of the "JK businesses," such as "JK rifure" (reflexology or massage), "JK satsueikai" (photo session) (Okunuki, 2015). Out of these variations, the most well-known one is "JK o-sanpo," in which a male customer takes a walk with a high school girl (Adelstein \& Kubo, 2015). The problems of the "JK businesses" lie with the existence of "secret options," which allows customers to have sexual interactions with the underage girls by paying extra service fees. Not every JK business ends up with sexual exploitation of minors, but most often, it does. In the annual human trafficking report released in 2014, the U.S. Department of State included Japan in the second tier, noting that enjo kosai and "JK walking" encourage minors to prostitute (United States Department of State, 2014). The report categorized 188 countries into three different tiers and the second tier includes countries that do not fully follow the Trafficking Victim Protection Act's minimum standards but are making efforts to comply with the standards.

\section{Current Legal Framework}

One of the features of the "JK businesses" is that they operate within the scope of laws (Bloch, 2015). In Japan, prostitution is restricted by Anti-Prostitution law which prohibits the sale and purchase of sex, but no judicial penalty is imposed on those who break the law (Anti-Prostitution Act). Instead, it criminalizes acts of soliciting for prostitution, coercing or deceiving a person into prostitution, and procuring a person for prostitution. The fundamental principle of the law is that prostitution harms human dignity and disturbs society, and sees those who prostitute as vulnerable in need of rehabilitation and social readjustment. However, the act states that if a person engaging in prostitution is under 18 years old, customers will be criminalized under the Act on Punishment of Activities Relating to Child Prostitution and Child Pornography, and the Protection of Children (1999). Also, under the Labor Standard Act, anyone under 18 is considered to be a minor and is not allowed to work in environments that are "dangerous or injurious to their safety, health welfare" (Oknuki, 2015). A related regulation is the Child Welfare Act, which bans "behaviors that put children under one's authority with the purpose of having them conduct themselves in a way that is injurious to the child's mental or physical health" (Oknuki, 2015).

Despite these laws prohibiting minors to engage in a business that is physically and mentally harmful to minors, the owners and customers of the "JK business" take advantage of loopholes that exist in the Japanese legal framework. For example, on May 12, 2016, the Tokyo Police arrested three suspects involved in a business in which high school girls folded origami with open legs and exposed their under skirts to male customers behind a magic mirror that could not be seen from the girls’ side (Adelstein \& Kubo, 2015). Customers would pay $¥ 5,000$ to $¥ 7,000$ (about $\$ 50$ to $\$ 70$ ) to look at the young girls' underwear for 40 minutes. The manager of the business told the police that he thought his business was legal because the girls were not just showing their underwear, but also doing legitimate work.

\section{Theoretical Explanations}

Since "JK business" is a rising issue, there is little literature regarding the business in Japanese or English. Therefore, it is crucial to explore its theoretical 
explanations to better understand the dynamics of the issue, to raise awareness, and ultimately to effectively regulate the "JK business." Theories chosen are gendered pathways theory and sexual script theory. Gendered pathways theory allows a focus on Japanese female minors' pathways into "JK business." From the theory, relational pathway model and social and human capital model are used specifically to analyze the pathways. Sexual script theory also adds the cultural context to the issue of "JK business" by evaluating the roles of Japanese cultural messages that promote the sexualization of high school girls. Both theories are appropriate to discuss cultural and social context that are unique to Japanese culture that drives "JK business."

\section{Gendered Pathways Theory}

Gendered pathways theory is categorized as a feminist theory that seeks to explain how certain life events such as trauma, economic marginalization, and mental health issues can create female pathways into various behaviors such as theft, drug use, and prostitution. These behaviors are labeled survival strategies or survival needs (Belknap, 2007). This section will introduce some criminalized survival strategies that female minors in "JK business" might engage in.

\section{The Relational Pathway Model}

The relational pathway model introduced by Salisbury and Van Voorhis (2009) explains that a dysfunctional relationship is associated with other risk factors such as adult victimization, low self-efficacy, depression/anxiety, and substance abuse. According to their study (2009), some of the characteristics of a dysfunctional relationship are a loss of sense of self and painful, unsatisfying, and unsupportive relationships. According to the survey of the girls who engaged in "JK business," $36 \%$ of the respondents indicated that their parents are not aware of their involvement with any "JK business," which shows the possibility that they have an unsupportive relationship with their family (Fujiwara, Shimizu, Takiyanagi, Nagao, \& Hoshi, 2016). Also, according to the same survey, the second most popular reason why they started working for such businesses is on the recommendation from their friends (Fujiwara et al., 2016).

Generally speaking, women are more likely than men to rely on their bonds with friends in solving problems (Salisbury, 2007). The results of the survey demonstrated a potential scenario for how a dysfunctional relationship played a role in the lack of a healthy and supportive relationship with their family. This lack of a healthy family relationship left the girls with unhealthy relationships with their peers who encouraged them to engage in "JK business."

Another risk factor that is often observed in females characterized by the model is depression/anxiety. There seems to be a tendency that girls longing for emotional attachment are susceptible to sex work as it was also the case with why enjo kosai tended to be more popular with depressed girls (Reid, 2010; Ueno, 2003).

Japan continues to have a high rate of depression among industrialized countries, and in the news articles about "JK business," it is often noted that the girls engaging in "JK business" suffer from some levels of depression and/or anxiety (Osaki, 2014; Reid, 2010). A 17-year-old Japanese female who worked for JK business said: "I was so depressed at the time that I didn't mind (being raped) if that's what a guy needed me for (Osaki, 2014).” 


\section{Social and Human Capital Model}

Another model to explain female pathways into "JK business" is social and human capital model. Social capital refers to resources available in people's social network that contributes to achieving their goals (Salisbury \& Van Voorhis, 2009). Quality and quantity of social ties beyond immediate family influence one's success in education and employment. While social capital is viewed as who you know, human capital can be perceived as what you know to succeed. Some of the examples of human capital are intelligence, skills, and personal confidence. The literature has demonstrated social and human capital as a key element for successful desistance from crime (Holtfreter, Reisig, \& Morash, 2004; Reisig, Holtfreter, \& Morash, 2002).

Although Japan is often portrayed as an industrialized and rich country, poverty exists throughout the country (Human Rights Council, 2016). Employment and financial difficulties are gender neutral risk factors; however, females can experience different obstacles than their male counterparts in obtaining employment. Gender inequality that still pervades in Japan can create certain obstacles specific to females, such as the gender gap in wage, difficulty getting paid maternity leave, and sexual harassment at workplace.

According to the 2016 Global Gender Gap Index reported by the World Economic Forum, Japan ranked 111th out of 114 countries (Hara, 2016). Japan especially struggles in providing women with economic opportunities that are equal to male counterparts. For minors experiencing economic hardship, the "JK business" can be appealing because they can make a significant amount of money in the short term. The attraction of "JK business"s is accentuated especially if they have disengaged from their family or are running away from their homes. According to a survey conducted by an advisory panel of experts on the "JK business," out of girls who worked for a "JK Business," (87.5\%) indicated that they got involved in the business for money (Fujiwara et al., 2016). Compared to other part-time jobs, JK business pays significantly better (Adelstein \& Kubo, 2015; Human Rights Council, 2016). Moreover, the studies have shown that the higher educated females among felony-convicted women had higher income and had a larger social network that provided them with more social and emotional support, which ultimately helped them stay away from recidivism (Reisig, et al., 2002).

\section{Survival Needs of Japanese Women}

In addition to dysfunctional relationships and economic hardship, Japanese females are faced with "survival needs" unique to Japanese women. As mentioned above, gender inequality is a serious social issue in Japan, and it can lead to establishing a sub-culture that influences female behaviors and mind-sets. Japan is known to have a sub-culture of kawaii or cuteness in Japanese language (Granot, Alejandro \& Russell, 2014). The sense of cuteness is associated with not only youthfulness but also pitifulness. In other words, cuteness can be demonstrated by any individual who appears to be weak or helpless. Because of these preferred personalities, young girls tend to act submissive, especially when confronted with older males. Their strategies of being "cute" involve hiding their intelligence and strength, appearing dependent and feigning stupidity. In the U.S., "girl power" is associated with independent, powerful, and opinionated women (Endresak, 2016). On the other hand, the term jyoshi ryoku, whose literal translation is "girl power," is commonly used in Japan to describe women who are feminine and submissive 
(Endresak, 2016; Granot et al., 2014). These survival needs that were produced as a result of gender inequality can challenge Japanese females, and some of them, unfortunately, are influenced to start their career as delinquents.

\section{Sexual Script Theory}

Dysfunctional relationships, economic hardship, and mental health problems are universally observed precursors to sexual exploitation, but one of the unique risk factors particular to Japanese society is sexualization of high school girls by the entertainment industry (Richardson, 2016). Although sexualization of female minors can be seen in other countries, Japan is a pioneer in commercializing and branding high school girls through animation, comics, and female idol groups ( $\mathrm{Hu}-$ man Rights Council, 2016; Richardson, 2016). Sexual script theory explains that deviant sexual behavior is a learned condition from being exposed to cultural messages that teach people what counts as sexual situations and how to act in such situations (Frith \& Kitzinger, 2001). According to O’Malley, Bachman, and Johnston (1996), greater deviance is induced when a deviant act is easier to act upon and followed by greater symbolic and tangible rewards (as cited in Farmer, McAlinden, \& Maruna, 2016).

\section{Sexual Scripts Through Fantasy}

Media can play a role in delivering messages to shape individuals' sexual norms. Japan is known for its sub-culture of comics and anime (Richardson, 2016). Both can provide the audience with predictable stages in encountering sexual settings, which is an essential element of the storylines. In particular, virtually generated images can easily demonstrate sexually deviant scenarios.

Until 2014, Japanese penal codes only banned production and distribution of pornography (Kyodo News Service, 2014). Simply possessing pornography, including child pornography was not criminalized. In 2014, the Diet approved a bill that was designed to amend the 1998 law on Punishment of Activities Relating to Child Prostitution and Child Pornography. However, the new law only applies to "real" pornography and does not include virtually created pornography, even if it depicts minors engaging in sexual activities. This relatively relaxed attitude toward the sexual depiction of minors is considered to be responsible for promoting sexual fantasies with minors.

Unlike the Freudian view that sexuality is inherent instinct, under sexual script theory, nothing about sexuality is assumed as long as a stimulus or a situation is attached to sexual desire (Wiederman, 2015). This logic can explain the production of paraphilia, which is "sexual arousal through deviant means" (Hickey, 2006). In the process of developing a paraphilia, people masturbate to their fantasy and attach sexual stimuli to the target objects or people. Therefore, fantasy is one of the most important elements to understand paraphilia. Paraphilia includes fetish: sexual attraction to objects, ephebophilia: sexual attraction to mid-to-late adolescents (approximately 15 to 19 years old).

As it was illustrated in the phenomenon of buru sera, school uniform is considered to be a symbol of high school girls; therefore, a majority of girls working for "JK businesses" wears a school uniform (Okunuki, 2015; Osaki, 2014). Two customers interviewed in a JK cafe mentioned that the school uniforms play a big role, saying, "The uniforms make them (the girls working at the cafe) look one and a half times cuter than they actually are" (Fifield, 2017). A manager of a "JK business" 
also admitted the importance of the uniforms, "Many Japanese men find something erotic in a school uniform" (Fifield, 2017). So, it is possible to say that some of the customers of the "JK business" are ephebophilic and are sexually attracted to teenage girls or have a fetish for school uniforms.

\section{Social-Sexual Scripts}

Sexual norms can also be conveyed through customs or laws because those can provide people with scripts by prohibiting or discouraging certain sexual activities (Wiederman, 2015). A central dogma of sexual script theory by Simon and Gagnon was the existence of gendered scripts because men and women experience different social situations (Frith \& Kitzinger, 2001). Male sexual scripts include actively seeking sexual partners and sex as a source of pleasure on their own, while female scripts are more submissive and associated with desires to please men. These gender differences can set a scenario of men buying the sexuality of younger women. Also, in addition to the fact that the police tend to admonish female workers more frequently than to arrest the male clients, ambiguity in Japanese laws concerning appropriate age for sexual conduct may obfuscate the responsibility of adults engaging in illegal sexual conduct with minors (Fujiwara et al., 2016).

The age of consent in Japan is 13 years old, which is considerably low compared to other countries (Waites, 2005). However, each prefecture has its juvenile obscene act and prohibits "unethical relationship" by individuals under the age of 18 , and this regulation is most commonly followed. But there is an exception to this act because the marriageable age in Japan is 16 years old for women and 18 years old for men with parental permission. Therefore, this could promote the misconception or justification that females over 16 years old, but under 18 years old, are allowed to have sexual conduct with adult males. In fact, there has been a longheld debate of whether the government should raise the age of consent from 13 to 18 (Osaki, 2017). However, even in the recent revision to the laws related to sex crimes, the supported change in the age of consent was not included.

\section{Discussions}

Gendered pathways theory discusses women's decision of engaging in delinquent activities as a coping or survival strategy responsive to their own needs (Salisbury, 2007; Salisbury \& Van Voorhis, 2009). Victims of sexual exploitation of the "JK businesses" are mainly minor females; therefore, gendered pathways theory allows focusing on factors that are unique to the population (Human Rights Council, 2016; Salisbury \& Van Voorhis, 2009). Also, this theory can be generalized to some other Asian countries with similar rates of achievement of gender equality, because the theory suggests that females have tendencies to be submissive and require a greater degree of initiation or provocation to commit crimes in such countries (Salisbury, 2007).

On the other hand, one of the shortcomings of the gendered pathway theory is that it is unable to explain how or where the delinquent pathway initially begins. Moreover, it fails to articulate why some girls get involved in prostitution, while others at the same levels of risk of delinquency do not. The most notable shortcoming of this theory is that according to the theory, those high school girls involved in the "JK business" are assumed to be not only victims but also delinquents. Stigmatization can worsen the girls' attitude toward authorities and rebel against them to commit more crimes or become more involved in the "JK businesses." 
Sexual script theory demonstrates cultural messages in society as a source of distorted moral behaviors and deviant sexuality (Farmer et al., 2016; Frith \& Kitzinger, 2001). An advantage of using sexual script theory is to be able to take two different approaches to crime; sociology and cognitive psychology (Frith \& Kitzinger, 2001). Both are crucial academic disciplines in explaining how some people learn distorted sexual practices. Especially when addressing a sexual offense specific to a certain population or a particular area, sexual script theory takes an interdisciplinary approach by increasing options available to address the problem. Also, the theory is designed to identify the source of sexual deviancy that can motivate people to commit sex crimes (Lam, 2003). Therefore, it can be used as a foundation to prevent other countries from starting the "JK businesses."

However, the theory fails to explain the existence of people who are exposed to the same cultural messages for sexual scripts but do not develop deviant fantasies (Frith \& Kitzinger, 2001). To provide a full explanation of sexual exploitation by the "JK business" customers, the theory needs to elaborate on individual variables that influence people's subjective interpretation of cultural or social messages.

Since the meaning of a message to a particular individual is highly subjective, the theory needs to quantify the factors that influence the interpretation. Each theory has both advantages and disadvantages to explain the emerging form of sexual exploitations of minors in Japan. This paper's purpose is not to conclude that a single theory explains the mechanism of "JK business." Instead, it aims to bring awareness to the issue that way more research work will be done to prove the need for its regulation.

\section{Policy Implications}

Since sexual exploitation in the "JK business" setting is an emerging issue in Japan, defining what constitutes the crime in relation to the "JK business" is a crucial stepping stone to regulate the illegal business. Currently, only two out of fortyseven prefectures have specific ordinances regulating the "JK business." In 2015, Aichi prefecture revised its ordinance of juvenile protection to specifically address the "JK business" (Tokyo Reporter, 2015). In 2017, Tokyo prefecture passed a very first ordinance specifically targeting the "JK business," which went into effect on July 1, 2017 (The Metropolitan Police Department, 2017). This bill defines "JK business" in details and bans juveniles aged 17 or younger from engaging in "JK business." Also, the bill allows the police to inspect "JK business" and made it clear that "JK business" owners' lack of knowledge of the age of their employees will not prevent them from being punished.

To prevent crime displacement, other 45 prefectures should follow after Aichi and Tokyo prefectures and set the same level of the "JK business" regulation and punishment, that way the "JK business" will not just diffuse to other prefectures. Furthermore, to prevent people from developing deviant fantasy on minors, sexually explicit materials that promote such scenarios, including child pornography and virtually created pornography should be strictly regulated. Therefore, the 1998 law on Punishment of Activities Relating to Child Prostitution and Child Pornography needs to be further amended to criminalize possession, production, and distribution of virtually created child pornography, which include comics and anime (Kyodo News Service, 2014).

Also, another standardized law needs to be created regarding minimizing children's exposure to sexually explicit materials. Today, in Japan, children have easy 
access to sexually explicit materials such as R-rated pornographic magazines (Osaki, 2016). For instance, in most convenience stores, there is a section for pornographic magazines, which is usually located near beverage sections. Some prefectures require the convenience stores to wrap R-rated magazines with strings that way people cannot open the magazines before purchase (Otake, 2016). The Diet should pass a bill to regulate the selling of sexually explicit magazines and comics in areas that are accessed by minors.

In February 2016, Sakai city in Osaka prefecture announced that they were taking the initiative to pass such an ordinance (Osaki, 2016). The ordinance is designed to mandate convenience stores to cover pornographic magazines with a semi-transparent green cover, which leaves the titles visible. The city started a pilot project in 10 convenience stores and requested a budget of $¥ 950,000$ (about $\$ 9,500$ ) for the initiative to provide the convenience stores with the semi-transparent covers (Otake, 2016). This strategy can be implemented in different cities and in prefectures as it is a way to prevent vulnerable populations of minors from being exposed to a possible source of sexual deviancy.

Moreover, the ambiguity in the laws concerning the age of consent needs to be clarified to reduce loopholes. The current Japanese Penal Code states that committing an indecent act upon or committing sexual intercourse with an individual under thirteen years of age is illegal (Human Rights Council, 2016).

Although there are no international laws or standard of the age of consent, Japanese age of consent being 13 is low compared to other countries: 16 seems to be the modal number among variations of the age of consent that exist worldwide (Waites, 2005). Although there have been some movements to raise the age limit, it has not been successful (Osaki, 2017; Waites, 2005). One reason why the age limit has not been raised may be because of the prefectural ordinance that prohibits sexual interaction committed by individuals younger than 18 years old, which is currently enforced in all the 47 prefectures (Human Rights Council, 2016). However, to prevent this ambiguity to promote the misconception that adults can have sex with minors between the age 14 and 17 years old, the Penal Code should be revised to raise the age limit to 18 years old.

Also, the wordings of some of the sex crime laws in Japan need to be changed. Article 176 and 177 of the Penal Code address forcible indecency and rape respectively, and in both articles, only acts done through threat or intimidation are defined to be illegal (International Models Project on Women's Rights, 2013). However, the definitions of sexual assault and rape in these laws need to be extended to clarify that minors cannot legally give consent to sexual interactions regardless of their willingness.

Also, another legal revision should be done on marriageable age. Currently, with parental consent, marriageable ages are 16 for females and 18 for males ( $\mathrm{Hu}-$ man Rights Council, 2016). Based on the law, it is possible to argue that if a female can marry at the age of 16 , then she should be able to legally consent to sexual intercourse with another adult. To avoid such confusion, the law should be changed to remove the age difference, and marriageable female age needs to be increased to 18 years old. Finding out the fine point between regulation and the liberation of female minors has been a struggle to many legal scholars internationally (Waites, 2005). However, in a country where sexualization and commercialization of female minors are common, their rights for sexual liberation should be regulated for the sake of protecting them. 
Also, minors sexually exploited or engaged in any "JK business" should not be labeled as minor prostitutes or criminals in order not to discourage them to report to the police. Until recently, because of the limited laws that were used to arrest and prosecute the "JK business" owners, the police were more likely to admonish the girls working for the "JK business" as a way to stop such illegal activity.

However, without arresting the owners, it is virtually impossible to shut down the business because the business will just be displaced somewhere else. Also, the girls who had worked in the business are a valuable source of information for research. However, it needs to be noted that any intervention for the "JK business" and interaction with the minors working for the business need to be conducted by agencies with adequate knowledge and training to avoid secondary victimization by the criminal justice system.

Lighthouse is a non-profit organization based in Tokyo, Japan, that works to eradicate human trafficking, especially sex trafficking in Japan. Some of the services they provide are confidential counseling and consultation for survivors of human trafficking, and education of law enforcement and other governmental agencies on how to recognize the human trafficking victims and investigate cases. The collaboration of such organizations will prevent secondary victimization of the survivors, and also help researchers conduct studies from the data they hold; therefore, a multidisciplinary approach to this social issue is essential.

\section{Conclusion}

The "JK business" is a new sex business emerged in Japan. The Japanese government and the law enforcement are faced with a great challenge of regulating the businesses because many of the businesses take advantage of loopholes in the current Japanese laws. This paper proposes the theoretical explanations of the "JK business" to be applied to such policies.

Two theories discussed in this paper suggest the following approaches to the JK business; 1) Gendered pathways theory allows related agencies to provide female minors with adequate help that meet their survival needs based on female characteristics, and 2) Sexual script theory intervenes sexual offenses by identifying social and psychological push factors of creating distorted sexual predilections (Farmer et al., 2016; Salisbury, 2007; Wiederman, 2015). Sexual Sexual exploitations of minors in the "JK business" settings require the immediate attention of researchers as the businesses continue to expand and victimize vulnerable teenagers. The Japanese government needs to fundamentally change their approaches to regulation of sex offenses to stop their infamous label as a "hentai (perverted) country."

\section{ACKNOWLEDGMENTS}

The author would like to express her sincere appreciation to Dr. Keith E. Clement, professor, Department of Criminology, California State University, Fresno, USA, for his continuous guidance, advice, and encouragement. The author also wishes to thank the editor-in-chief of Dignity, Donna Hughes, and the reviewers for their insightful comments and comprehensive advice on earlier versions of this paper. Dignity thanks the following people for their time and expertise in reviewing this paper: Cassini Sai Kwan Chu, honorary lecturer, Department of Sociology, The University of Hong Kong; Erin C. Heil, associate professor, Department of Criminal Justice Studies, Southern Illinois University, Edwardsville, USA; and Christine Zozula, assistant professor, Sociology and Anthropology Department, University of Rhode Island, USA. 


\section{AUTHOR BIOGRAPHY}

Mutsumi Ogaki received B.S. in Criminology with an emphasis on Forensic Behavioral Science from the California State University, Fresno. She currently works as a research associate in the Department of Criminology at the university to examine violence intervention strategies using social network analysis. Her research interests include social network analysis, community context of crime, and gender inequality issues. Born and raised in Japan, she is also interested in examining cultural and social risk factors particular to sex offenses in Asian countries.

\section{RECOMMENDED CITATION}

Ogaki, Mutsumi. (2018). Theoretical explanations of joshi kousei (“JK business") in Japan. Dignity: A Journal of Sexual Exploitation and Violence. Vol. 3, Issue 1, Article 11. https://doi.org/10.23860/dignity.2018.03.01.11

\section{REFERENCES}

Adelstein, J., \& Kubo, A. E. (2015, July 20). In Japan, teenage girls folding paper cranes has taken on a whole new meaning. Vice News. Retrieved from https://news.vice.com/article/in-japan-teenage-girls-folding-paper-cranes-hastaken-on-a-very-different-meaning.

Baishun boushi hou [Anti-Prostitution Act.] Act No. 118 of May. 24, 1956. As last amended by Act No. 63 of 2016. Retrieved from http://elaws.egov.go.jp/search/ elawsSearch/elaws_search/lsg0500/deta il?lawId=331AC0000000118.

Belknap, J. (2007). The invisible women: Gender, crime, and justice (3rd ed.). Belmont, CA: Thomson Wadsworth.

Bloch, B. (2015). High school prostitution in Japan's sex industry. Politics \& Policy. Retrieved from http://politicsandpolicy.org/article/high-school-prostitutionjapan\%E2\%80\%99s-sex-industry.

Colombo, J. (2012). Japan's bubble economy of the 1980s. The Bubble Bubble. Retrieved from http://www.thebubblebubble.com/japan-bubble/

Endresak, D. (2016). Girl power: Feminine motifs in Japanese popular culture. (Unpublished doctoral dissertation). Eastern Michigan University, Michigan. Retrieved from http://commons.emich.edu/cgi/viewcontent.cgi?article=1321\&context=honors

Farmer, M., McAlinden, A. M., \& Maruna, S. (2016). Sex offending and situational motivation: Findings from a qualitative analysis of desistance from sexual offending. International Journal of Offender Therapy and Comparative Criminology, 60. https://doi.org/10.1177/0306624X16668175.

Fifield, A. (2017, May 16). For vulnerable high school girls in Japan, a culture of 'dates' with older men. The Washington Post. Retrieved from https://www.washingtonpost.com/world/asia pacific/For-vulnerable-highschool-girls--in-japan-a-culture-of-dates-with-older-men/2017/05/15/974146c4035d-11e7-9d14-9724d48f5666 story.html?utm term=.c022ad5f1245

Frith, H., \& Kitzinger, C. (2001). Reformulating sexual script theory: Developing a discursive psychology of sexual negotiation. Theory \& Psychology, 11,209-232. Retrieved from http://journals.sagepub.com/home/tap 
Fujiwara, S., Shimizu, N., Takiyanagi, K., Nagao, T., Hoshi, S. (2016). Iwayuru JK business ni okeru hanzai boushi taisaku no arikata ni kansuru houkokusyo ( いわゆる $J K$ ビジネスにおける犯罪防止対策の在り方に関する報告書). Retrieved from http://www.gender.go.jp/kaigi/senmon/boryoku/siryo/pdf/bo83-2.pdf

Granot, E., Alejandro, T. B., \& Russell, L. T. M. (2014). A socio-marketing analysis of the concept of cute and its consumer culture implications. Journal of Consumer Culture, 14, 66-87. https://doi.org/10/1177/1469540513485274

Hara, K. (2016, Oct 26). Japan ranks 111 th $_{\text {in }}$ gender equality. Nikkei Asian Review. Retrieved from http://asia.nikkei.com/Politics-Economy/Policy-Politics/Japanranks-111th-in-gender -equality.

Hickey, E. W. (2006). Sex crimes and paraphilia. Upper Saddle River, NJ: Prentice-Hall Publishers.

Holtfreter, K., Reisig, M. D., \& Morash, M. (2004). Poverty, state capital, and recidivism among women offenders. Criminology \& Public Policy, 3,185-208.

Human Rights Council. (2016). Report of the special rapporteur on the sale of children, child prostitution and child pornography on her visit to Japan. United Nations Human Rights Office of the High Commissioner. Retrieved from http://www.ohchr.org/EN/Issues/Children/Pages/ChildrenIndex.aspx

International Models Project on Women's Rights. (2013). Current legal framework: Rape and sexual assault in Japan. Retrieved from http://www.impowr.org/content/current-legal-framework-rape-and-sexualassault-japan

Jidou baishun jidou poruno ni kakawaru koui tou no kisei oyobi syobatsu narabini jidou no hogo tou ni kansuru houritsu [Act on Regulation and Punishment of Acts Relating to Child Prostitution and Child Pornography, and the Protection of Children.] Act No. 52 of May. 26, 1999. as last amended by Act No. 79 of 2014. Retrieved from http://www.japaneselawtranslation.go.jp/law/detail/?ft=2\& $\mathrm{re}=02 \& \mathrm{dn}=1 \& \mathrm{yo}=$ prostitution $\& \mathrm{x}=54 \& \mathrm{y}=18 \& \mathrm{ky}=\&$ page $=1$

Kyodo News Service. (2014, Jun 18). Japan parliament enacts law to ban possession of child pornography. BBC Monitoring Asia Pacific.Retrieved from http://search.proquest.com/docview/1536616723?accountid=10349

Lam, O. W. (2003). Why did enjo kosai anchor in Taiwan but not in Hong Kong? Or the convergence of "enjo" and "kosai" in teenage sex work. Inter-Asian Cultural Studies, 4, 353-363. https://doi.org/10.1080/1464937032000113051

Mason, F., \& Lodrick, Z. (2013). Psychological consequences of sexual assault. Best Practice Research Clinical Obstetrics and Gynaecology, 27. Retrieved from https://doi.org/10.1016/j.bpobgyn.2012.08.01508.15

Nagoya cops bust 'JK' parlor. (2015, June 28). Tokyo Reporter.Retrieved from http://www.tokyoreporter.com/2015/06/28/nagoya-cops-bust-jk-parlor/

Okunuki, H. (2015, May 24). Society helps sustain Japan's sordid sexual trade in schoolgirls. The Japan Times. Retrieved from http://www.japantimes.co.jp/community/2015/05/24/ issues/society-helpssustain-japans-sordid-sexual-trade-schoolgirls/

Osaki, T. (2014, Nov 4). Notorious 'JK' business exploits troubled high school girls for sex. The Japan Times. Retrieved from http://www.japantimes.co.jp/news/ 2014/11/04/national /social-issues/notorious-jk-business-exploits-troubledhigh-school-girls-sex/\#.WFDCXPn hBKN

Osaki, T. (2016, Feb 17). Japanese city seeks to cover up adult magazines in convenience stores. TheJapan Times. Retrieved from http://www.japantimes.co.jp/news/ 2016/02 /17/national/japanese-city-seeks-cover-adult-magazines-conveniencestores/\#. WFBQqPnhC00 
Osaki, T. (2017, Jun 16). Diet makes historic revision to century-old sex-crime laws. The Japan Times. Retrieved from http://www.japantimes.co.jp/news/2017/o6/16/ national /politics-diplomacy/diet-makes-historic-revision-century-old-sexcrime-laws/\#.WVX iiYjhC00

Otake, T. (2016, Apr 6). Osaka prefecture city works with FamilyMart to cover up adult magazines. The Japan Times. Retrieved from http://www.japantimes.co.jp/ news/2016/04/06/national/social-issues/osaka-prefecture-city-worksfamilymart-cover-adult-mag azines/\#.WFIDw_nhC00

Reid, J. A. (2010). A pathway to child sex trafficking in prostitution: The impact of strain and risk-inflating responses. (Doctoral dissertation). Graduate Theses and Dissertations. Retrieved from http://scholarcommons.usf.edu/etd/1747

Reisig, M. D., Holtfreter, K., \& Morash, M. (2002). Social capital among women offenders: Examining distribution of social networks and resources. Journal of Contemporary Criminal Justice, 18,167-187.

Richardson, M. W. (2016). Marketing affect in Japanese idol music. (Doctoral dissertation). Retrieved from ProQuest LLC. (10117196).

Salisbury, E. J. (2007). Gendered pathways: An empirical investigation of women offenders' unique paths to crime. (Electronic Thesis or Dissertation). Retrieved from https://etd.ohiolink.edu/

The Metropolitan Police Department. (May 15, 2017). JK business wa kiken desu. (JK ビ ジネスは危険です). Retrieved from http://www.keishicho.metro.tokyo.jp/ kurashi/higai/kodomo/jkb_kiken.html

Ueno, C. (2003). Self-determination on sexuality? commercialization of sex among teenage girls in Japan. Inter-Asia Cultural Studies, 4,317-324. https://doi.org/10.1080/1464937032000113060

United States Department of State. (2014). Trafficking in persons report. Retrieved from http://www.state.gov/documents/organization/226844.pdf

Waites, M. (2005). The age of consent: Young people, sexuality, and citizenship. London, UK: Palgrave Macmillan. doi:10.1057/9780230505933

Wiederman, M. W. (2015). Sexual script theory: Past, present, and future. Handbooks of the Sociology and Sexualities, 1,7-22. https://doi.org/10.1007/978-3-319-17341$\underline{2} 2$ 